AL-AZHAR UNIVERSITY

BULLETIN OF THE FACULTY OF

LANGUAGES \& TRANSLATION
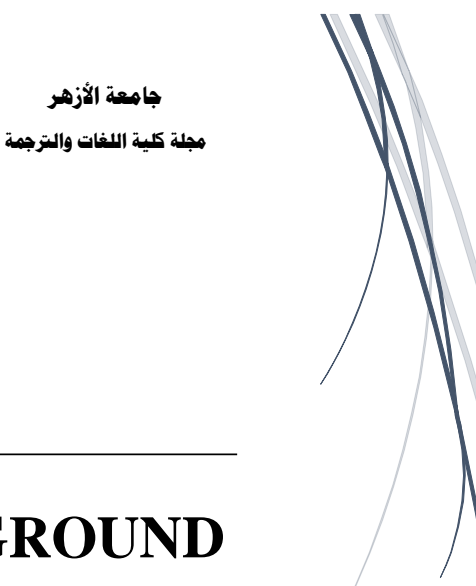

Saber Fouad Muḥammad Mahmoud

\title{
TO THE RISE AND EVOLUTION OF SHÎ'ISM \\ A HISTORICAL BACKGROUND
}

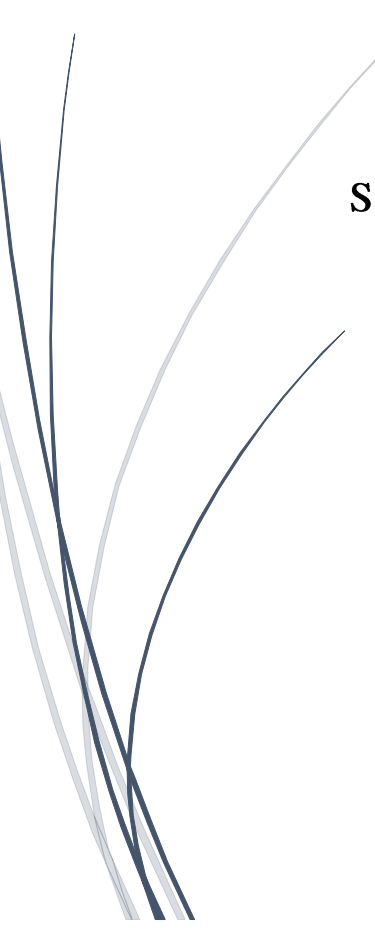




\title{
A HISTORICAL BACKGROUND TO THE RISE AND EVOLUTION OF SHÎ'ISM
}

Saber Fouad Muhammad Mahmoud

Department Of Islamic Studies In Foreign Languages (English Section), Faculty Of Languages\& Translation, Al Azhar University, Cairo, Egypt.

Email: saberfouad2425.el@azhar.edu.eg

\begin{abstract}
:
The majority of Imâmî scholars, known as twelvers, believe that the Prophet explicitly appointed 'Alî as his successor and consequently, illegitimate the caliphate of the first three caliphs. However, other Shî'ite sects outside the twelvers, like the Zaydîs, legitimize their succession. For Imâmîs, 'Alî and his sons are the inheritors of Prophethood. They claim that Prophethood passes on to the descendants. The concept of imamate for Imâmîs, is a continuous divine obligation and that the Imam is divinely selected and infallible. Whatever the Imâmî scholars try to argue, their claims were refuted by Sunnî scholars who comment that 'Ali gave his allegiance to them, accepted to work with them willingly and gave his daughter Umm Kulthūm to 'Umar in marriage. In addition, the groups that constituted the army of "Alî did not represent a regular party with absolute obedience to 'Alî or common attitude towards his family. The Sunnî scholars subscribe to the view that the word Shî' ah was used at that time in the pure literal sense which means followers and supporters. The word was used to describe either sides; it was said shî 'at 'Alî and shî 'at Mu'âwiyah. Therefore, the rise of Shî'ism was merely political and Husayn's martyrdom marks the beginning of the transformation of Shî' $a h$ from a political movement to distinctive religious sect within Islam. In other words, Shî'ism evolved during the Umayyad dynasty but it took firm roots during the Abbasid reign. The issue of Succession played a vital role in the evolution of Shî 'ism. There are the moderates and ghulat (radicals) of Shî'ah. Among the different Shî'ite sects, the twelvers represent the majority of Shî'ah nowadays.
\end{abstract}

Keywords: The Rise Of Shî‘ism, Imamate, Shî‘ite Sects, Saba'îs, Foreign Elements In Making Shî‘ism

$$
\text { خلفية تاريخية لنشأة التشيع وتطوره }
$$

$$
\text { قابر البرايد الإلكتروني: محمد محمود الإسلامية باللغات الأجنبية (شعبة اللغة الإنجليزية)، كلية اللغات والترجمة، جامعة الأزهر، القاهرة، مصر. }
$$

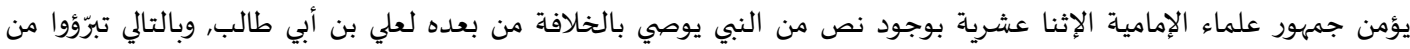

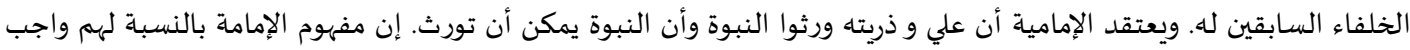

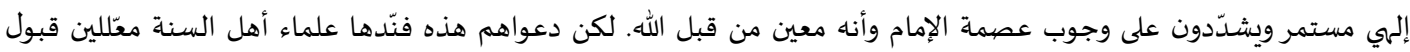

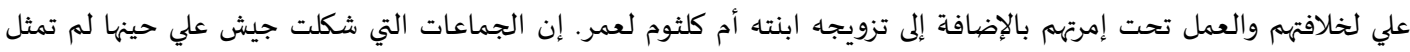

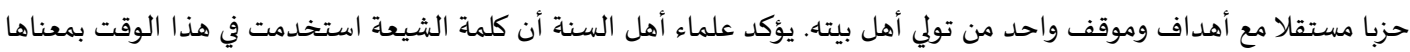

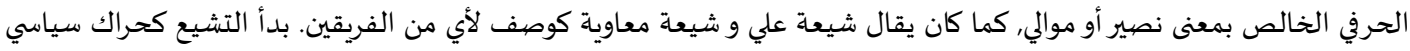

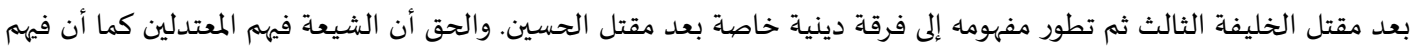

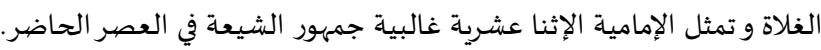
الكلمات المفتاحية: نشأة التشيع، الإمامة، فرق الشيعة، السبإية، العناصر الأجنبية في صنع التشيع. 


\section{INTRODUCTION}

The end of 'Uthmân's reign witnessed the insemination of alien ideas in naive minds, which soon turned to devilish schemes seeking to wreak strife in Muslim community. The easy-going Policy which 'Uthmân adopted in his governance beside the revolt in some governorates demanding 'Uthmân to remove their governors, this over-lenient approach led some ignorant people to show no respect to the caliph to the extent that they demanded him to step down. In addition to that, the virtuous companion Abū Dharr al-Ghifârî introduced the idea of equal distribution of wealth among all Muslims. This claim found huge numbers of supporters especially among the poor class. All these problems would not have been so effective but for the patronage of 'Abdullâh Ibn Saba' . (Al-Ṭabarî 1387 AH, 4/340) Though few noble companions, like Muhammad Ibn Abū Bakr and Muhammad Ibn Abū Ḥudhayfah, were opposing to 'Uthmân, this opposition was because of personal reasons. The former was a supporter of 'Alî because they were related to each other. As for the later, he opposed 'Uthmân because 'Uthmân did not appoint him for any political position. (Ibn Kathîr 1988, 7/191) When the news of the complaints of the people of the provinces reached the caliph, he delegated four of the noble companions to discuss these complaints. He sent Usâmah Ibn Zayd to Başrah, Muḥammad Ibn Maslamah to Küfah (both in Iraq), 'Abdullah Ibn 'Umar to Syria, and finally 'Ammâr Ibn Yâsir was sent to Egypt. The first three delegates returned with the result that these claims had no basis. But 'Ammâr was deceived by some people in Egypt who managed to sway him to their side. Those people included 'Abdullâh Ibn Saba', Kinânah Ibn Bishr and others. (Al-Ṭabarî $1387 \mathrm{AH}, 4 / 341)$

'Uthmân issued an announcement to all provinces that those who had a complaint should present before the caliph to file their petitions, but none filed any complaint. However, the rebels continued their uprising the matter that showed that it was not mere individual complaints. The situation proved to be worse than that. Some of those who were hostile to the caliph marched to Medina (lit. al-Madînah) with the intention of deposing him. They conspired to kill him but he was informed about their conspiracies. Some companions advised him to retaliate them to get rid of their dangers. However, 'Uthmân, out of his leniency, did not listen to the advice of the companions. Instead, he started negotiating them and persuaded them with the majority of his answers. To their resentment, the rebels took advantage of

\footnotetext{
${ }^{1}$ He was a Jewish who claimed to be a Muslim at the reign of 'Uthmân. He harbored his resentment to Muslims and sought to spread mischief making use of the political disorder at the end of 'Uthmân's reign.
} 
people's anger with 'Uthmân's policy, particularly appointing his relatives in public offices, and incited people against him. 'Uthmân wisely handled the matter and sent to the governors of the provinces to meet with him to discuss the urgent issues. When 'Uthmân consulted the matter with the governors and ordered them to show leniency with the rebels, they refused to abide by these orders and blamed him for not dealing strictly with them before the matter had deteriorated to that extent. (Ibn Kathîr 1988, 7/187) 'Uthmân never expected that people would breach their pledge of allegiance. In year $35 \mathrm{Ah}$, some people from Egypt and Iraq set for hajj (pilgrimage to Makkah) harboring their true intentions; which is to demand the caliph to remove the governors of their provinces. If he refused, he should resign, otherwise, they would use force. (Ibn Kathîr 1988, 7/194)

A letter with 'Uthmân's seal, in which 'Uthmân orders the governor of Egypt to kill the negotiators upon their return to Egypt, was forged. (Al-Ṭabarî $1387 \mathrm{AH}$, 4/355) This matter sow bitter hatred against the caliph and instead of returning to their homes, the negotiators went to the caliph and showed him the letter, which he disclaimed. (Ibn Kathîr 1988, 7/196) Then, they asked that his scribe should be presented. 'Uthmân refused lest they may kill him. They insisted on their demand which he refused to answer. (Ibn Kathîr 1988, 7/202) Upon persistence in his stance, the rebels lay a siege to 'Uthmân's house and prevented him from going out. (Ibn Kathîr 1988, 7/198) 'Uthmân sent a letter to the people of the Muslim provinces and as soon as the letter reached. Troops were directed to Medina to lift the siege. (Al-Ṭabarî 1387 AH, 4/351-352) The young people like al-Ḥasan, alHusayn and 'Abdullâh Ibn al-Zubayr hastened to save the caliph and provided him with water and food. The instigators decided to end their mission before the support came to the caliph. They tried to break into 'Uthmân's house, but some companions resisted them. After a siege lasted twenty days, some of the rebels climbed the walls of the caliph's house and attacked him while he was reciting the Qur'an. This strife did not end at 'Uthmâns death. Another file of violence and mischief continued during the reign of the fourth caliph. The conspirators insisted on enforcing their plots against Islam and persisted in instigating Muslims against each other. These plots were headed by 'Abdullâh Ibn Saba' who started to inject his ideas into the Muslim community making use of these disorders. The ensuing war between 'Alî and $\mathrm{Mu}$ 'âwiyah left some ignorant people who were seduced by the ideas of Ibn Saba' and introduced some alien beliefs which afterwards constituted the basis for the rising Shî' ite beliefs. 


\section{The definition of $S h \hat{\imath}$ 'ism}

\subsection{The lexical definition}

The Arabic word Shi'ah is derived from the root word shaya'a, which means to support and be partisan of somebody. In Lisân al- 'Arab, Shî'ah denotes a distinct group of people who agree with one another in following a cause. Shî'ah literally means a partisan of somebody. Al-Azharî says: Shî'ah are those who follow each other's opinions, albeit they are not totally in agreement. (Ibn Manzūr n.d., 188-199) This term was commonly understood as the partisans of 'Ali and his family. Later on, it became a special designation for them. When it is said: so and so are Shî'ah or follow their Madhhab , it is understood that they belong to that specific group. (AlZabîdî n.d., 303) In the days of Sahâbah, this term was used to be understood in its very literal sense, and became widely used at the time of disagreement between 'Ali and Mu'âweyah; every one of them had his own followers and supporters (Shî'ahs). Later on, the term was used to designate that political party; those who consider the succession to the Prophet to be the special right of the family of the Prophet and follow the school of the prophet's household. The author of A'yân al-Shì'ah writes:

"...Then after the death of 'Uthmân and the rebellion of Mu'âwiyah with his party against 'Ali asking the revenge for Uthmân's murder, Mu'âwiyah managed to recruit a great number of Muslims, who became known as "Uthmânîs and the followers of "Ali was called "Alawîs." ( Al-Amîn 1983, 1/19) (Trans. is mine)

\subsection{The definition of Shî'ism according to Shî'ite scholars}

Shî'ite scholars insist on giving Shî'ism an earlier origin, claiming that its origin dates back to the time of the Prophet, or even before. The word Shi' $a h$ is defined by al-Nawbakhtî as a reference to 'Alî's party, called as Shî'ah of 'Ali ('Alî's partisans) in the days of the prophet and after him, they are known for following 'Alî and confessing his Imamate (succession to the prophet). (Al-Nawbakhtî 2012, 51) Almufîd- known as Shaykh of Shî'ah-claims that the word Shî'ah may be added to another word, for example: Shî'ah of 'Alî or Shî'ah of Banū Umayyah, etc. but when the definite article (al-, the) is added, the term becomes special for the followers of 'Ali, who believe that the succession to the prophet is his due right and denounce the succession of the former caliphs. (Al-Mufíd $1413 \mathrm{AH}, 35$ ) This definition explicitly repeals the succession of Abū Bakr and 'Umar. As noticed also in other words of al-Mufîd in the book of al-Irshâd; he states that The Imamate of 'Ali after the prophet was supposed to be thirty years. For twenty-four years, he 
was deprived of taking it over and did not demand it practicing Taqiyyah (dissimulation of faith), as it was the situation with the prophet who, out of fear, was forced to conceal his Da wah for some years in Makkah. (Al-Mufîd 2008, 1/9) This claim, no doubt, is vain as it opposes what the Muslim majority believe of the validity of the caliphate of Abū Bakr and 'Umar. Besides, it is not expected from such a noble and courageous knight like "Alî to harbor a desire for succession, if found, for that long period out of fear or cowardice. Moreover, we do not need to fend off the false accusation of the prophet's concealment of 'Ali's right to succession after him whatever reasons were found. All Muslims believe that the prophet delivered the message of Allah intact as revealed to him with no addition nor omission. Had this been the right of "Alî, it would have been mentioned explicitly in the Qur'an or the Sunnah of the prophet.

In the book of al-Zinah of Abu Hâtim al-Razî, Shî'ah is a term given to those who accompanied 'Alî, in the days of the messenger of Allah and were affiliated to him... it was said Shî'ah of 'Alî. (Al-Amîn, 2001, 1/19) As noticed, these definitions have no reference whatsoever to the most prominent tenets of Shî ism, like the succession after 'Ali, the chain of alleged Imâms, Naşş and Waşiyah. That means that these tenets crept into Shî 'ism by later generations of Shî' $i$ scholars.

\subsection{The definition of $S h \hat{\imath}^{6}$ ism according to Orientalists}

Orientalists view that the term Shî'ah as a designation for the partisans of "Alî against those of 'Uthmân. The partisans of "Alî preferred him to other companions of the Prophet and believed (and still believed by present Shî' $a h$ ) in the Naşş for 'Alî, the existence of an explicit statement of the Prophet to inherit the Imamate. In the encyclopedia of Islam:

"... It refers to the movement upholding a privileged position of the Family of the Prophet (ahl al-bayt) in the political and religious leadership of the Muslim Community. The name is derived from Shî'ah i.e. the party or partisans of 'Ali, which was first used in the inter-Muslim war during Ali's caliphate distinguishing them from the Shî 'ah of 'Uthmân, the partisans of the murdered caliph 'Uthmân opposed to "Alî." (Boswoth 1997, 9/420)

Julius Wellhausen asserts the late rise of the term Shî'ah upon the murder of 'Uthmân. At that time, he comments, Islam divided into two parties, the party of 'Alî and that of Mu'âwiyah. The party in Arabic is called Shî'ah. Thus the Shî'ah of 'Alî countered the Shî' 'ah of Mu'âwiyah. But when Mu'âwiyah was appointed as ruler of Muslim state, the term Shî' ah became confined to those who followed "Alî." (Wellhausen 1958, 146) The term, to orientalists, was merely political. The 
opposition to 'Uthmân was inherently a political and social revolt but later acquired a religious form. (Guillaume 1956, 117) It was used to differentiate between the two opposing parties: the party of 'Alî confronting the party of Mu'âwiyah. Thus it will be nonsense to claim that the term has any existence before 'Ali's caliphate.

\subsection{The definition of $S h \hat{\imath}$ 'ism according to Sunnî scholars:}

The definitions of Shî'ism by Sunnî Scholars suggests that the term has varied understandings. They assert its political origin and refuse to confess its existence before 'Alî's caliphate. Al-Ash'arî (d.324) states that the word Shî'ah means those who adhered to 'Alî and preferred him to any companion of the prophet. (Al-Ash'arî 2005, 1/25) While Ibn Hazm (d. 456 AH) asserts the centrality of Imamate in defining the term. He states that whoever believes 'Alî is the best of men after the messenger of Allah and the most deserving of Imâmah (Muslim leadership) and so are his descendants after him is a Shi' $\hat{\imath}$, even if he differs in beliefs other than what we have just mentioned, otherwise, he is not." (Ibn Hazm n.d., 2/90) It is worth mentioning that later Shî 'ite scholars adopt the definition of Ibn Hazm, as they find it more inclusive than that of earlier Shî̀ite scholars; whose definitions did not mention the succession after 'Alî. Noticeably, the notion of Shî̀ism varied over ages. At early times, it meant the group that supported 'Ali politically and preferred him to 'Uthmân. Later words were added to the definition to digest the developed creeds.

Al-Shahrastânî (d. 548 AH) says that Shî'ah are those who give special adherence to 'Alî Ibn Abū Ṭâlib and confess, secretly or publicly, his right to Imamate through Naşs (a report from the Prophet) or Waşiyyah (by legacy). They believe, he continues, that Imamate should not fail any of his descendants, and if it were to fail any of them, it would be an act of oppression and usurpation by a rival or a practice of Taqiyah (dissimulation of faith). (Al-Shahrastânî n.d., 1/146) Though this definition mentions Naşş and Waşiyah, it is still free of other Shî' $\hat{\imath}$ creeds like Ghaybah (occultation), Raj ' $a h^{2}$ or Badâ'. Al-Suyūṭ̂ (d. 911 AH) in his Tafsîr does not mention any special definition of the word Shî 'ah other than its general notion, as diverse parties. In Qur'ân: (6: 65), al-Suyūṭ̂ interprets the word Shî'ah as meaning "different parties". In (Q. 6: 159), he comments: "It means different parties, innovating sects and heretics. "Abdul-Razzâq narrated through his chain from Qatâdah who said: "They are the Jews and the Christians..." (Al-Suyūṭ̂ n.d., 3/403)

\footnotetext{
2 the belief that Shi ite Imams will return to this world before the day of resurrection to retaliate for their oppression and to enforce justice.
} 


\section{The emergence of $S h \hat{\imath}$ 'ism}

\subsection{The emergence of $S h \hat{\imath}^{\top}$ ism according to Shî'ite scholars}

Shî'ite scholars hold different views about the exact date of the birth of Shî' ism. Some allege that it started even before the prophet's message, and every prophet of Allah was asked to believe in 'Alî's Wilâyah, and that it was ordained along with Tawhîd (Islamic monotheism) to all creations, for it the covenant was taken, and prophets were sent. Shî' ite scholars build their understanding on (Q.3:81) they view that the covenant has been taken from the prophets to believe in the message of the Prophet Muhammad and to support 'Alî. Al-Bahrânî reports from Abū 'Abdullâh (Imam Ja'far) who said that Allah has not sent a Prophet from Adam, and so forth, except that he would return to this world and support 'Alî, and that Allah's saying \{and you must support him\}, Means to support 'Alî, And Allah, he continues, never sent a Prophet nor a messenger except he made a Covenant for Muhammad with the Prophethood and for "Alî with the Wilâyah". (Al-Baḥrânî, 2006, 2/60-61) The view that Wilayah, the core of Shî ism, is preached along with Tawhîd is also articulated in a narration by al-Kulaynî from Abu Ja'far (Imam Muhammad alBâqir) who interprets the Ayah \{The Trustworthy Spirit [i.e., Gabriel] has brought it down\} (Q.26:193), as a reference to the legality of the Wilayah of "Alî. (Al-Kulaynî 2007, 1/259)

For some Shî' is, the Prophet was the first one to put the seed of Shî'ism, and some Şahâbah befriended "Shâya 'a" "Alî at the time of the prophet. Al-Qummî says that the partisans of 'Alî Ibn Abu Țâlib were called Shî'ah of 'Ali at the time of the prophet and after him, known for their loyalty to him ('Alî) and used to confess his right of Imamate. He names some companions of the Prophet as partisans of 'Alî, like: al- Miqdâd, Salmân, Abu Dharr, 'Ammâr and some others. (Al-Qummî $1321 \mathrm{AH}, 15)$ While some other Shî' ite scholars claim that it dates back to the death of the prophet and the difference about the most deserving one of succession to him. Al-Nawbakhtî states that Muslims were divided into three groups after the Prophet's death. One group was called Shî' $a h$, who were the partisans of 'Ali, and from them the different sects of Shî' $a h$ have emerged. (Al-Nawbakhtî 2012, 31)

Ibn al-Nadîm (d.384 AH) dates the rise of Shî 'ism back to the battle of al-Jamal ${ }^{3}$ stating that when 'Alî directed to Țalhah and al-Zubayr to fight them so that they may submit to Allah's command, as he claims, those who followed him then were

\footnotetext{
${ }^{3}$ a revolution against 'Ali, during his reign, by some companions to demand the revenge for 'Uthmân's murder.
} 
called Shî'ah, as "Alî used to call them "my Shî'ah". (Ibn al-Nadîm 1997, 217) As for al-Ṭabațabâ'î, he views that Shî'ism started with a reference made for the first time to the partisans of 'Ali (shî' at 'Ali), during the lifetime of the Prophet himself. (Al-Ṭabatabâ'î 1975, 34) However, in the following pages, he declares that the main cause behind the emergence of Shî'ism was the difference about the right to succession after the Prophet. He says:

"They protested against the act of choosing the caliph by consultation or election, and also against those who were responsible for carrying it out...It was this protest and criticism which separated from the majority the minority that were following "Ali and made his followers known to society as the "partisans" or "shî 'ah" of "Ali." (Al-Ṭabațabâ'î 1975, 36)

Other Shî 'ite scholars hold different opinions on the emergence of Shî 'ism which are contrary to the above claims. For example, Muhammad Ḥusayn Kâshif al-Ghitâa' says that Shî'ism or Shî' 'ah had no existence at that time (the reign of Abu Bakr and 'Umar) as he believes Islam was on its sound grounds at this period. (Al-Ghitâa' 1990, 124) This statement of Kâshif al-Ghitâ' excludes the existence of Shî'ism before the era of 'Uthmân and suggests that there were no basis for it at the time of the first two caliphs. This view may agree partly with the Sunnî suggestion that the conspiracies made at the end of 'Uthmân's time played a vital role in planting some Shî'ite creeds by Ibn Saba', which were the kernel for the evolution of Shî'ism in the following decades.

\subsection{The emergence of $S h \hat{\imath}^{\dagger} i s m$ according to Orientalists:}

Orientalists incline to date the birth of Shî 'ism back to the clash between 'Alî and Mu'âwiyah after the death of 'Uthmân. (Wellhausen 1958, 146) In the encyclopedia of Islam, "The Shî'ah first formed an identifiable movement in Islamic history during the First Civil War between 656 and 661 C.E...Shî'ism as a movement, however, burst into full view with the assassination of 'Uthmân and the ensuing civil war." (Stewart 2003, 621) The encyclopedia of the Qur'an also states that the term was used to differentiate between the followers of 'Alî and 'Uthmân's. It asserts that 'Alî's followers were called Shî'at 'Alî as also the partisans of 'Uthmân were called Shî 'at 'Uthmân. (Leaman 2006, 590) While Strotnmann views that Husayn's murder was the start of Shi 'ism as a creed. (Boswoth 1997, 14/59) It is obvious that orientalists uphold the view that Shî 'ism started to rise at the end of 'Uthmân's reign. No one claim it was found before that time. 


\subsection{The emergence of Shî‘ ism according to Sunnî scholars}

Sunnî scholars, in one way or another, agree that Shî 'ism had no existence before the era of 'Uthmân. Nevertheless, it first emerged as a political movement. Later on, Shî' $a h$ developed into theological sect and began to discuss their theological beliefs on a more theoretical level. Ibn Hazm dates the birth of Shi 'îsm back to the dissent in Muslim community after 'Uthmân's reign. He states that Shî'ah rose as an ensuing ramification of that dissent. (Ibn Hazm n.d., 2/76) While Ahmad Amîn views that the seed of Shî'ism was planted on the Prophet's death and grew afterwards. He argues that the first seed of Shî 'ism was planted by that group of Muslims who believed that the Prophet's family members, particularly 'Ali, had a better claim to succeed the Prophet after his death in leading Muslim community. (Amîn n.d., 266) It is clear that technical shî'ism had no roots at the time of the companions of the Prophet. It was adopted after Husayn's murder, but reference was

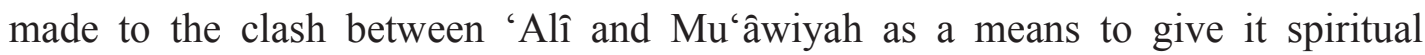
sanctity. This is substantiated by the words of al-Dhahabî who argues that the Shî 'ite extremists during the early generations of Islam were those who were notorious for speaking ill and showing disrespect to Prophet's companions, especially those who fought against 'Al i. (Al-Dhahabî 1963, 1/6) Iḥsân Zahîr infers that in the first era of Islam, the term Shî' $a h$ was used literally to refer to a political party, and was widely used at the time of clash between 'Alî and Mu'âwiyah. (Zahîr 1995, 37) Modern researchers subscribe to this view. (Al-Sawwâh 2010, 19) To Ibn Taymiyah, the term had no existence in the time of Abū Bakr or 'Umar. During the caliphate of Abū Bakr and 'Umar, he adds, no one was called Shî' $i$ and none was referred to as such" (Ibn Taymiyah 2004, 2/40) this view is also substantiated by the words of Imam Muhammad Abū Zahrah who says that their doctrines emerged at the end of 'Uthmân's age and were nourished at the time of 'Alî... and when 'Alî's descendants were oppressed and negated at the time of Umayyads, the scope of Shî'ism widespread and gained more followers. (Abū Zahrah n.d., 30)

Aḥmad al- Ghâmidî in his book about Shî'ism, concludes that Shî'ism is of two kinds. First: political, that emerged because of political reasons and objectives. $\mathrm{He}$ says" political Shî'ism rose at the time of 'Uthmân; some people took the side of 'Uthmân while others preferred 'Ali without negating the previous caliphs...thus the term was not confined to the Shî' ah of "Alî" (Al-Ghâmidî 2010, 22) Second: dogmatic, that has an earlier ideological basis started with the figure of 'Abdullah Ibn Saba' who was the main founder and indoctrinator of Shî 'ism. Al-Ghamidî states that a Jewish character appeared at the time of 'Uthmân, claimed himself a Muslim 
and injected new dogmas that later became the basis for Shî 'ism. That character was 'Abdullâh Ibn Saba'. (Al-Ghâmidî 2010, 23-24)

\section{Foreign elements in making Shî‘ism}

The tenets found in Shî 'ism seem to have a foreign background and basis, be it Persian, Jewish, or Christian. These tenets proved themselves as unfamiliar and alien to the mainstream Muslim creed and are deemed far-fetched from the spirit of Islamic faith.

\subsection{The Persian element}

The special partisanship of Persians to Imam al-Husayn and his progeny is particularly affected by the Persian heritage and ancient dogmas; the Persians exaggerated in honoring and glorifying their ancient kings, history and ancestors. Some believe that their fore king "Keyumars" 4 is the first son of Adam, and they are the origin and first seed of humanity." (Al-Shahrastânî n.d., 2/41)\& (Al-Gharîb 1981, 19) When Muslims conquered Persia, al-Husayn Ibn 'Ali married the daughter of Yazdgerd, who came with the captives. This is a fundamental reason why the Persian Shî'ites give a special privilege to Imam al-Husayn and his progeny; that is because they are believed to have a Persian blood owing to that marriage. (Al-Gharîb 1981, 57)

Shî'ah also celebrate the day of (al-Nayrūz, or Nawrūz), an old feast of the Zoroastrians. (Al-Maqrîzî 1418 A.H, 34) It appears in Tâj al'arūs that al-Nayrūz is a Persian but were Arabicized during the dynasty of Banū 'Abbâs. (Al-Zabîdî n.d., 15/349) This is confirmed also in the encyclopedia of Islam which states that Nawruz was observed in Zoroastrian Persia and has long been celebrated in areas influenced by Persian culture. (Stewart 2003, 506) Moreover, they gave to Salmân, the Persian, the rank of an infallible prophet or a revered Imam; and a later group even elevated him to divinity. (Al-Ash'arî 2005, 1/30-31) Persians used to ascribe to themselves a supreme status; they assumed that others should be servants to them. They felt they were in a grave calamity when their kingdom evaporated at the hands of the backward-they assumed- Arabs. This matter provoked their conspiracies against Muslim community in several times. (Ibn Ḥazm n.d., 2/91)

Imâm Muhammad Abū Zahrah asserts the Persian influence on the matter of succession. He expounds that Arabs were accustomed to free ruling while Persians believed in hereditary system... He comments that the resemblance in the ruling

\footnotetext{
${ }^{4}$ appeared in medieval Zoroastrian texts as Gayōmard or Gayōmart
} 
system and dynasticism, he suggests, reflects a notable influence of the Persian system that lead to the shî 'ite prejudice to a ruling family. (Abū Zahrah n.d., 34-35) This resemblance was affirmed by the author of al-Tuhfah al-Ithna 'ashariyyah as well. (Dahlawî 1373 AH, 300)

\subsection{The Jewish and Christian elements:}

The Jewish and Christian influence on shî 'ite doctrines cannot be denied as it was confessed by some Shî 'ite scholars, though others try to object to this fact. These doctrines infiltrated in Shî'ism at the hands of Ibn Saba', a Jewish from Yemen who appeared at the time of 'Uthmân and instigated some people against him in a revolt which ended with the murder of the third caliph. Sa'd al-Qummî says:

"'Abdullâh Ibn Saba' was a Jew; then he turned Muslim and claimed 'Alî's
friendship. When he was a Jew, he had formed an exaggerated opinion
regarding Joshua, the heir of Moses. So when he embraced Islam after the
Prophet's death, he asserted the same opinion in respect of 'Alî. He was the
first to proclaim the Divine Imamate of 'Alî. On this ground, the opponents
of the Shî 'ites say that the origin of Shî 'ism is from Judaism." (Al-Qummî
1321 AH, 20) (Trans. is mine)

'Abdullâh Ibn Saba' was among those who claimed for 'Alî the Jewish conception of God-man. This is maintained by Al-Baghdâdî (d. 429 AH) who states that Ibn Saba' planted some Jewish creeds among his followers and claimed that 'Alî will return to this worldly life. (Al-Baghdâdî 1977, 223) Shî' 'ah, influenced by the teachings of Ibn Saba', said about 'Alî like that which Christians say about the Prophet Jesus who, they claim, has a divine nature. (Al-Baghdâdî 1977, 225) The author of al-Tuhfah al-Ithna 'ashariyyah mentions some influences by Judaism and Christianity. He states that the Jewish said 'leadership cannot fit save a man from the family of Dawūd (David, the Prophet)'. Likewise, Shî 'ah assume that leadership has to be confined to the descendants of 'Alî. (Dahlawî 1373 AH, 298) Shî'ah are likened to the Jews also in attributing regret and remorse to Allah. This regret appears in the Shî 'ite cult of Badâ' and is articulated in the Old Testament. (AlJumaylî n.d., 317) In the book of (Exodus, ch.32: 14): "the LORD repented of the evil which he thought to do unto his people". In al-Burhân, it is stated that Shî'ah resemble the Jews in their statement that the Hell fire, in the Day of Judgment, will not touch them except for few numbered days. This view is presented in connection with the interpretation of (Q.2: 80). (Al-Bahrânî, 2006, 1/261) There are more aspects of resemblance between the beliefs of Shî' $a h$ and that of the Jews which can 
be seen in the Jews and the Christians claim they are the chosen and loved ones by Allah. Shî'ah likewise, allege they are elected by Allah and are preferred to others.

\section{Shî'ite sects}

United by a belief that Imamate (leadership of Muslim community) is an exclusive right of the members of the Prophet's family, distinct groups have arisen throughout Shî'ite history differing about who is to be entitled to succeed in that position. Therefore, Shî 'ah is known to be subdivided into many sects, whose numbers are counted by some scholars to exceed sixty or seventy. (Al-Qifârî, 1994, 1/90) The number of Shî'ite sects in some books, like "al-Maqâlât wa al-Firaq" by al-Qummî and "Firaq al-Shî'ah" of al-Nawbakhtî, exceeds sixty sects. The doctrinal differences of these sects are not so significance except in the case of Zaydîs, who is believed to be more moderate than any of the other Shî'ite sects. The Shî'ite sects primarily can be divided to three major sects: Saba'îs, Zaydîs and Imâmîs (which is subdivided into Ismâ 'îlîs, Ithnâ 'asharîs and some others).

\subsubsection{The Saba'îs}

Many contemporary shî 'ite scholars attempt to deny the existence of 'Abdullāh Ibn Saba' as a true historical figure. They have written a great number of books that primarily aim at denying that such person ever existed in history. In all their writings, they describe the story of "Abdullâh Ibn Saba' to be a "fairytale," "legendary," "mythical" etc. for instance, Hasan al-Amîn writes that the story of 'Abdullâh Ibn Saba' was made by the enemies of Islam whose goal is to split the Muslims. According to al-Amîn, those so-called "enemies of Islam" claim that Shî' 'ah is a sect originated by 'Abdullâh Ibn Saba'. It is stated in the shî 'ite encyclopedia that Saba'is were affiliated to the tribe of Saba' in ancient Yemen whose story was mentioned in (Q34:15) and they were known as such till the middle of the second century (of Muslim calendar). As for the character of Ibn Saba', he argues that it was invented by a man named Sayf Ibn 'Umar al-Tamîmî, who ascribed to Ibn Saba' the introducing of shî'ite doctrines. (Al-Amîn, 2001, 13/182-185) This is a fail and invalid attempt made by shî'ite scholars to deny the influence of Saba'îs in injecting alien beliefs, on which the present shî 'ite doctrines are based. The reality of Ibn Saba' was proved in many of shî'ite sources. For example, in his book on Shî 'ite sects, al-Nawbakhtî declares that the first sect to show extremism was Saba'îs, the disciples of 'Abdullâh Ibn Saba' who disparaged Abū Bakr, 'Umar, 'Uthmân and other companions of the Prophet and rejected them 
as legitimate rulers. Confessing that, 'Alî condemned him to death; some people asked 'Alî: "O, Commander of the Faithful, are you killing a man who calls people for loving you, the household of the Prophet, for allying with you and disassociating themselves from your enemies? Instead, 'Alî banished him to alMadâ'in. (Al-Nawbakhtî 2012, 57) Ibn Saba' went to the far extreme to claim Prophethood to himself and divinity to 'Alî. Al-Ṭūsî reports through his chain from Abu Ja'far (Muhammad al-Bâqir) his saying: "Abdullah Ibn Saba' claimed he was a prophet and 'Alî was God (Allah)!! When this news reached 'Alî, he asked that Ibn Saba' be brought to his presence. Having confessed his crime, 'Alî ordered that he be burnt to death" (Al-Ṭūsî, 1427 AH, 102) \& (Ibn Ḥazm n.d., 4/142)

The historical existence of 'Abdullâh Ibn Saba' was proved by many Sunnî scholars, including al-Ṭabarî, Ibn al-Athîr, Ibn Qutaybah, al-Dhahabî, alShahrastânî and al-Baghdâdî. Al-Ṭabarî reports that Ibn Saba' was a Jewish from San'â' (A city in Yemen). He converted to Islam at the era of 'Uthmân and decamped around Muslim countries. He started deceiving the people of Hijâz (Arabia), passing by Başrah, Küfah (both in Iraq), and then the Levant where he was disclaimed. Afterwards, he went forth to Egypt where he was welcomed somewhere. He claimed that Prophet Muhammad will return after death and 'Alî was his legatee and will return as well... (Al-Ṭabarî 1387 AH, 340) Ibn al-Athîr also mentions the same story about him and that he was a Jewish who claimed himself to be a Muslim at the time of 'Uthmân accusing him of usurping 'Alî's legitimate right to succession. To propagate these allegations, he dispersed his agents and deputies in Muslim territories. (Ibn Al-Athîr 1997, 526) Al-Dhahabî in his Mîzân stated that 'Abdullâh Ibn Saba' was an extreme heretic and misleading deviant who is supposed to have been burnt with fire. Ibn Saba' assumed that the present Qur'an is only one of nine parts whose knowledge is exclusive to 'Alî, though 'Alî forbade him from assuming that. (Al-Dhahabî 1963, 2/426)

Al-Shahrastânî substantiates the existence of a sect named Saba'îs, the disciples of 'Abdullâh Ibn Saba' who said to the noble 'Alî 'you, you are the one (God). 'Alî exiled him to al-Madâ'în... he was the first one to invent a text assuming the legacy to 'Alî and from him, the extreme denominations emerged. He assumed that 'Alî is still alive, is partly man and partly God (God-man), and will return to this life to fill the earth with justice. (Al-Shahrastânî n.d., 1/174) Al- Baghdadî also mentions the Saba'îs, the followers of 'Abdullâh Ibn Saba', he says that Ibn Saba' was exiled to alMadâ'in. When 'Alî was murdered, Ibn Saba' claimed that the dead body was not 'Alî's, but was a demon in his image. As for 'Alî, Ibn Saba' assumes, he ascended to 
heaven as did Jesus, the son of Mary. (Al-Baghdâdî 1977, 223-224) Thus, the Sunnî scholars assert the historical existence of the Saba'is, and emphasize their influence on most of the present Shî 'ite beliefs.

\subsubsection{Saba'î doctrines}

The present shî 'ite doctrines are primarily based on Saba' $̂$ beliefs. They believed in Immanentism, the immanence of the spirit of God in 'Alî. This immanence is to be transformed through his noble progeny one after another. Ibn Saba' and his companions used to describe 'Alî as the God incarnate; they said to him 'you are 'HE' The God', thereby 'Ali burnt them. (Abū Zahrah n.d., 36) Saba'îs reiterate the claim of Ibn Saba' that 'Ali did not die and is still alive. They assume that he will die only after he has spread justice on earth. Al-Nawbakhtî states that a sect called Saba'îs, the disciples of 'Abdullâh Ibn Saba' said that 'Alî was not murdered nor was thought to be dead, and he won't, till he hits Arabs with his crook and fill the earth with justice and fairness as it was filled with injustice and oppression. (AlNawbakhtî 2012, 57) A similar statement about Saba'îs is stated by Ibn Hazm in alFişal. (Ibn Ḥazm n.d., 4/138)

Saba'is were the first sect to show extremism in Islam. They started with the statement that 'Alî was a prophet. Subsequently, they went further to assume that he was a God, a genuine God, in addition to the saying that he is still alive riding the clouds. (Al-Asfrâiînî 1983, 123-124) Saba'îs also introduced the issue of succession by legacy and confined the legitimacy of Muslim leadership to 'Alî and his descendants. Those statements Ibn Saba' used to say about Yūsha' Ibn Nūn ${ }^{5}$ when he was a Jewish. (Al-Qummî 1321 AH, 20)

\subsection{The dissent of $S h \hat{\imath}^{6} a h$ after the death of al-Husayn}

During the imamate of 'Alî, al-Ḥasan, and al-Husayn. Shî' ah did not undergo any divisions. Subdivisions arose after the martyrdom of al-Husayn, the majority of Shî' ah adhered to the imamate of 'Alî Ibn al-Husayn, al-Sajjâd, while Kîsâniyyah accepted Muhammad Ibn al-Hanafiyyah as the fourth Imam as well as the promised Mahdî, and that he had gone into occultation and would reappear. After the death of al-Sajjâd, the majority of Shî'ah accepted his son, Muhammad al-Bâqir, while a minority followed Zayd and became known as Zaydîs. Following al-Bâqir, the Shî'ah accepted his son Ja'far al-Şâdiq, then Mūsâ al-Kâzim, the seventh Imam. At that stage, one group followed the older son of the sixth Imam, Ismâ'îl and became

\footnotetext{
${ }^{5}$ Joshua, the leader of the Israelites after the death of Moses
} 
known as Ismâ'îlis. After al-Kâzim, the majority followed his son, 'Alî al-Riḍâ. The chain continued to the twelfth Imam, whom the majority of Shî' ah believe to be the promised Mahdî. Any following division was not so significant. The majority of the Shî'ite sects disappeared within a short period, except three ones: Zaydîs, Ismâ'îlîs and Twelvers, who represent the majority of Shî'ah nowadays. We shall limit our discussion to these three subdivisions, which continue to exist until now.

\subsubsection{The Zaydîs}

Zaydîs are the adherents of Imam Zayd, the son of 'Alî al-Sajjâd. The followers of Zayd regard him as the fifth Imam of the Household of the Prophet. After him, they followed his son, Yahyâ, followed by his progeny. At the beginning, the Zaydîs, following the example of Zayd, considered the first two, Abu Bakr and 'Umar, as legitimate Imams. But after a while some of them began to delete the name of the first two caliphs from the list of Imams and claimed 'Alî to be the first legitimate Imam. (Al-Țabațabâ'î 1975, 70) From what is known of the Zaydî beliefs, they follow an approach close to that of the Mu'tazilites in $U s ̧ \bar{u} l$ (fundamentals of the faith), , while in Furü' (the branches of the law), they apply the jurisprudence of Abu Hanîfah, the founder of one of the four Sunni schools of law. They also differ among themselves concerning some minor issues. (Ibid, Zaydîs are deemed to be the most moderate sect within Shî'ah and the closest to the majority of Sunni Islam. They do not elevate their Imams to the position of Prophethood nor do they exaggerate in praising them, rather, they believe they are just noble humans. Moreover, they do not accuse any one of the companions of the prophet of disbelief, particularly those whom 'Alî had given allegiance. (Abū Zahrah n.d., 40) Zaydîs also have undergone subdivisions throughout history. Zayd used to accept Abū Bakr and 'Umar, yet preferring 'Alî above all. When he heard those who defame them, he renounced that and forbade them. However, they refused to abide by Zayd's instructions and continued their practices. Later on, they were divided, concerning some questions, to Jârūdîs, the followers of Abu al-Jârūd who again aroused the issue of legacy of succession; Sulaymânîs, the followers of Sulaymân Ibn Jarîr al-Zaydî who believed that Imamate is a matter of consultation, in addition to al-Batriyyah. (Al-Ash'arî 2005, 65-69) It is worth mentioning, Zaydîs nowadays differ, in some aspects, from those who accompanied Imam Zayd. 


\subsubsection{The Ismâ'îlis}

Ismâ îliss is a branch from Imâmîs and was named after Ismâ'îl, the oldest son of the sixth Imam, Ja'far al-Şâdiq. Ismâ‘îl died during the lifetime of his father. Concerning this question, some believed that Ismâ'îl did not die but went into occultation, and would appear again as the promised Mahdî. Another group believed that the true Imam was Ismâ'îl whose death meant the imamate would transfer to his son Muhammad and his descendants. (Al-Nawbakhtî 2012, 114115)\& (Al-Shahrastânî n.d., 167) Ismâ îlîs has undergone a certain divisions. Sab 'iyyah (related to number "seven"), as they believe that Ismâ'îl was the seventh and the seal in the chain of Imams, albeit his descendants may inherit the position. They also assume that the system of the Underworld, i.e. the Orbit, owes to the role of the major seven planets: Saturn, Jupiter, Mars, the Sun, Venus, Mercury, and finally, the Moon. (Al-Ghazâlî n.d., 16) This philosophy is similar to that of the Şâbi'ah (star worshippers). (Al-Ṭabațabâ'î 1975, 70) There are another two sects within Ismâ'îlîs: Muhammirah, it is thought they were named as such because they used to paint their clothes in red, or because they stigmatized their rivals as Hamîr (donkeys). Ta limiyyah (the masters of teaching) is another sect characterized by the need for an infallible Imam who has the absolute right to teach and instruct. They deny knowledge obtained through reason and mere opinion. (Al-Ghazâlî n.d., 17) This description also fits the Bâtinîs who believe that each exterior teaching (Zâhir) has an inner aspect (Bâtin) and each element of revelation (Tanzîl) has a hermeneutic and esoteric exegesis $\left(T a^{\prime} w \hat{\imath} l\right)$. (Al-Ṭabațabâ'î 1975, 71)

Ismâ îlis believe that the earth can never fail to have Hujjah (Proof) of Allah. Hujjah is two kinds: "speaker" (nâtiq) and "silent one" (Şâmit). The speaker is a prophet and the silent one is an Imam who is Waşî, the executor of the testament of a prophet. A prophet, they believe, who is the perfect manifestation of God, has the esoteric power of initiating men into the divine Mysteries. After him, they claim, there are seven Waşîs who possess the power of executing his testament and the power of esoteric initiation into the Divine Mysteries. (Al-Ṭabațabâ'î 1975, 71) Ismâ îlis believe that Adam was sent as a prophet with Prophethood and esoteric guidance and that he had seven executors of whom the seventh was Noah. Likewise, Abraham was the seventh executor of Noah, Moses was the seventh executor of Abraham, Jesus was the seventh executor of Moses, Muhammad was the seventh executor of Jesus, and likewise, Muhammad Ibn Ismâ'îl was the seventh executor of Muhammad. They claim that the waşis of the Prophet are counted seven, the chain of whom starts with 'Alî, al-Husayn....and ends with 
Ismâ'îl Ibn Ja'far. ${ }^{6}$ After this series, they assume, there are seven descendants of Muhammad Ibn Ismâ‘̂il whose names are hidden and secret. Ismâ 'îlîs also believe that beside the Proof of Allah (Hujjah), there should always be on earth twelve Naqîbs (chiefs)who are the elite followers of the Hujjah. (Al-Salūmî 2001, 1/585590)

\subsection{Al-Ithnâ'ashariyah (The Twelvers or Imâmîs)}

The Twelvers represent the largest sect within Shî 'ism. They were named as such as they believe in a chain of twelve Imams of the household of the Prophet, starting from 'Alî Ibn Abū Ṭâlib, his son al-Ḥasan, followed by al-Husayn, the second son of 'Alî. The chain continues after that through the descendants of al-Husayn until it reaches the twelfth Imam who is believed to have gone into occultation and would reappear as the promised Mahdî. (Al-Baghdâdî 1977, 47) Al-Ash'arî says that they were called Imâmîs due to the statement that the legitimate Imams after the Prophet are 'Alî and his household. Imâmîs believe that Imams were assigned by their names one after another. 'Alî assigned al-Hasan to be the Imam after him, likewise, al-Ḥasan assigned al-Husayn and al-Husayn assigned his son 'Alî. Then comes his son Muḥammad, Ja'far, Mūsâ, 'Alî, Muḥammad, 'Ali, al-Ḥasan and his son Muhammad ibn al-Ḥasan, known as al-Mahdî. (Al-Ash'arî 2005, 17-18) The author of A'yân al-Shî'ah mentions that Twelvers are the largest sect of Shî'ah that exists today, followed by the minority of Zaydîs and Ismâ îlîs. (Al-Amîn 1983, 1/20) AlMufîd asserts the existence of a Prophetic Naşş (text) that obligates the following of the infallible Imams. That is why those who believe in the Naşs and the Imams are called Imâmîs. He states that the term Imâmîs designates those who believe in the obligation of the Imamate and its due existence over times, and also confess the obligation of the Naşs which nominates the infallible and perfect Imams by their names and that the sucession to the Prophet has to be the exclusive right of the descendants of al-Husayn. (Al-Mufîd $1413 \mathrm{AH}, 38$ ) The description of Imâmîs as Twelvers has arisen after the death of al-Hasan al-'Askarî, the eleventh Imam (d.260 AH). Before this date, none counted the twelfth Imam as a promised Mahdî. Controversies have arisen about his existence. Some denied his birth and others said he died while his father was still alive. The proof of his absence before his father's death is that his brother, Ja'far, claimed his inheritance from al-Hasan who had died leaving no inheritor except him. (Ibn Taymiyah 2004, 4/87) Ibm Hazm named them Qat 'iyyah and Râfị̂h because they believe in the certain death of Mūsâ, al-Kâzim and refuse to accept Abū Bakr and 'Umar. They, he adds, assume that Muhammad

\footnotetext{
${ }^{6}$ they rule Imam al-Hasan, the brother of al-Husayn, out of the chain
} 
Ibn al-Hasan is still alive and will never die, but will reappear to fill the earth with justice. To them, he is the promised Mahdî. (Ibn Hazm n.d., 4/138)

Imamîs assume that the nomination of an Imam was the duty born by the Prophet. He had to cut it clear and should not leave it to debates and unguided consultation. Al-Shahrastânî defines Imamîs as those who view Imamate is the exclusive right of "Alî Ibn Abū Ṭâlib and was proved by a clear text and definite nomination by the Prophet. The Prophet, they guess, not only mentioned the Imams by description, but also nominated them with names. They hold the view that religion has no pillar more important than the nomination of the Imam, since a prophet's duty is to remove conflict and to establish accord. Therefore, they believe that the Prophet nominated "Alî explicitly and sometimes, implicitly. (AlShahrastânî n.d., 1/162) Imâmîs also believe that the twelfth Imam, Muhammad Ibn al-Ḥasan al-'askarî has gone into occultation hiding inside a vault in his father's house at Surra-man-ra'â (an old city in Iraq). They differ about his age at the time of disappearance. It is said he was whether four or eight. They also differ about his authority at that time. Some claim that he had the qualifications of an eligible Imam who is worth obedience. Others viewe that authority was held by responsible scholars. (Abū Zahrah n.d., 46)

\subsection{The status of Imamate}

To Imâmîs, an Imam has the full authority to legislate and enact the laws; every single word he says is a faith, as he is not expected to contradict the faith. They assume that Imamate is a position like prophethood; should be treated as the divine revelation. They add that Imams were to be selected out by God as prophets were. A prophet receives laws through divine revelation, but Imam, who bears the duty to complete the prophet's job, is believed to receive them through prophetic inspiration. (Al-Ghitấ' 1990, 134) Being so serious position, Imâmîs argue, Imamate entails an infallible and wise Imam. This means that Imam is neither expected to err or commit a foolish act, nor does it fit him to forget. Al-Ṭūsî views Infallibility is a vital prerequisite for him (Imam) as well as great knowledge. Since Imam, in Imâmîs faith, is veritably well-versed in every single thing his community may need; it does not suit him to be less knowledgeable or inferior in rank than any one of his community." (Al-Ṭūsî, 1928, 1/80) Moreover, Imâmîs claim the occurrence of supernatural matters at the hands of Imam as a sign of his Imamate and, incline to call this $M u$ 'jizah (a miracle given to a prophet as a sign of his Prophethood) exactly like what happened with the prophets of Allah. Al-Ṭūsî claims that Because infallibility cannot be perceived through senses, proves for it cannot be set except through a clear text, or through the exhibition of miracles -as an alternative of a text- to substantiate the Imamate of an Imam. (Al-Ṭūsî, 1928, 1/276) 
Imam not only have to be infallible, but also, he should have a good command of everything related to Sharî' 'ah (Islamic theology), the knowledge of the explicit, the implicit, the outward and the inward meanings of legal texts. He is believed to be responsible for all religious matters, be they serious or trivial. His knowledge is believed to be divinely inspired, and not gained through human teaching; as Imam is, as believed, not expected to exert his effort in issues above his capacity and still there probability of error of judgment; i.e. he is not apt to involve in uncertain knowledge, rather, his judgments is based on doubtless knowledge through inspiration. (Abū Zahrah n.d., 49) Imâmîs, though diverse, agree on the sacredness of the position of Imamate; the status of an Imam should not be questioned. To them, it is close to that of a prophet, equals it or even, as some assume, excels it. Those who view the status of Imam as superior to or higher in rank than that of a Prophet make use of the Qur'anic Ayah (Q2:124), there in Abraham was tried by Allah with commands and he fulfilled them. Thereafter, Allah said that Abraham will be made an Imam (leader) for people. They infer from this Ayah that Abraham was granted Imamate as a higher degree after he has completed the mission as a prophet! They argue that the above Ayah refers to the tests to which Allah exposed the Prophet Abraham after his Prophethood at the end of his life. Having successfully passed these tests and patiently withstood the great hardships, they assume, he was granted the position of Imamate. (kardan n.d., 15)

These statements concerning Imam and Imamate have no sound basis. They are based on sheer conjecture and can be easily refuted. The infallibility is proved only to the prophets of Allah. Imam is a normal human who is apt to err and could be elected through general or restricted consultation, nomination or other suitable and accepted procedures. Imamate for Sunnî majority is a political position, to watch over the interests of the community in the light of Shar 'i rules. (Al-Khudarî 1982, 8-11) As for the legacy for 'Ali and his descendants to inherit the position of succession to the Prophet in leading Muslim community, "Ali himself stated that if he were to claim that position, it would be due to his close relation with the prophet and did not mention anything about the existence of a text or legacy. Imam Muslim reports in his Şahịh 'Alî's statement to Abū Bakr: "...We had a right (to be consulted) on account of our kinship with the messenger of Allah". (Al-Mundhirî 1987, 2/306) This report states that 'Alî mentioned only one thing that gave him a right to be consulted concerning the position of Caliphate, which is his kinship with the prophet. He did not mention any word about the existence of a text of legacy (Naşş). If there had been a so called bequest made by the Prophet, it would have been approved and enforced by the Prophet's companions. (Al-Khuḍarî 1982, 7) 


\section{CONCLUSION:}

In their attempt to promote Shî'ism, Imâmî scholars resort to esoteric exegesis as an attempt to substantiate their support to 'Alî's household. Imâmî scholars are of the opinion that the three caliphs (Abu Bakr, 'Umar and 'Uthmân) are not worthy of the caliphate, but their claim was refuted by Sunnî scholars who argue that 'Alî gave his allegiance to them, accepted to work with them willingly and gave his daughter Umm Kulthūm to 'Umar in marriage. The majority of Imâmî scholars, known as twelvers, believe that the Prophet explicitly appointed 'Alî as his successor and consequently, illegitimate the caliphate of Abū Bakr. However, other Shî'ite scholars outside the twelvers, like the Zaydîs, legitimize the succession of Abu Bakr. In other words, for the twelvers, there is a text (naşş) which stipulates the Prophet's testament (waşiyyah) for 'Alî; however, for the latter, there is no such a text. For the Imâmîs, 'Alî and his sons are the inheritors of Prophethood. They claim that Prophethood passes on to the descendants. The concept of imamate for Imâmîs, is a continuous divine obligation and that the Imam is divinely selected and infallible.

Whatever the Imâmî scholars try to give their Faith an earlier origin to the time of the Prophet himself, their opinions have no sound basis. The groups that constituted the army of "Alî did not represent a regular party with absolute obedience to 'Alî or common attitude towards his family. The Sunnî scholars subscribe to the view that the word Shi 'ah was used at that time in the pure literal sense which means followers and supporters. The word was used to describe either sides; it was said shî́'at 'Alî and shî'at Mu'âwiyah. The evidence to that is the words of al-Dhahabî about Busr Ibn Arța'ah: " ...and was of the Shî'ah (supporters) of Mu'âwiyah." (Al-Dhahabî 2003, 2/793) Therefore, the rise of Shî̀ism was merely political and none can allege that it emerged before the era of 'Uthmân, rather, its origin was late, precisely, by the end of 'Uthmân's reign ensuing the rebellion instigated by 'Abdullâh Ibn Saba', the Jewish. Thus, it was political in nature and Husayn's martyrdom at Karbala marks the beginning of the transformation of Shî'ah from a political movement to distinctive religious sect within Islam. (Stewart 2003, 625) In other words, Shî‘ism evolved during the Umayyad dynasty but it took firm roots during the Abbasid rule. It is noticeable that Shî'ah were characterized by the over-diversity to many sects. The issue of Succession played a vital role in this respect, and was the essential axis for this diversity. Shî'ah also were divided regarding the degree of deep stuck to Shî'ism. There are the moderates and radicals (ghulât) of Shî' $a h$. Among the different Shî' ite sects, the Twelvers represent the majority of Shî'ah nowadays. 


\section{Bibliography}

Abū Zahrah, Muhammad. Tarîkh al-Madhâhib al-Islâmiyah. Cairo: Dâr al-Fikr al'Arabî, n.d.

Al-'Assâl, Muhammad Muhammad Ibrâhîm. Al-Shî' ah al-Ithnâ 'ashariyyah wa Manhajuhum fî Tafsîr al-Qur'ân,. 1. Cairo: Mațba'at Manşūr, 1427 AH.

Al-Amîn, Ḥasan. Dâ'irat al-Ma 'ârif al-Shî 'iyyah. 6. Beirut: Dâr al-Ta'âruf, 2001.

Al-Amîn, Muhsin. A'yân al-Shî'ah. Edited by Ḥasan Al-Amîn. Beirut: Dâr alTa'âruf, 1983.

Al-Asfrâî̀nî, Ṭâhir b, Muḥammad. Al-Tabşî̀ fî al-Dîn. 1. Beirut: 'Alam al-Kutub, 1983.

Al-Ash'arî, Abū Al-lḤasan 'Alî b. Isma'îl b. Isḥâq. Maqâlât al-Islâmiyyîn wa Ikhtilâf al-Muşalliyîn. 1. Cairo: al-Maktabah al-`a!riyah, 2005.

Al-Baghdâdî, 'Abdulqâhir b. Ṭâhir b. Muḥammad. al-Farq Bayna al-Firaq. 2nd. Beirut: Dâr al-Afầq al-Jadîdah, 1977.

Al-Baḥrânî, Hâshim. Al-Burhân Fî Tafsî r al-Qur'ân. 2. Beirut: Mu'assasat AlA'lamî, 2006.

Al-Baḥrânî, Yūsuf Aḥmad. Lu'lu'at al-Baḥrayn. 1. Maktabat Fakhrâwî, 2008.

Al-Dawūdî, Muhammad b. 'Alî b. Aḥmad. Ṭabaqât al-Mufassirîn. Beirut: Dâr alKutub al-Isâlmiyyah, n.d.

Al-Dhahabî, Muḥammad Al-Sayid Ḥusayn. Al-Tafsîr wa al-Mufassirūn. Cairo: Maktabat Wahbah, n.d.

Al-Dhahabî, Shams Al-Dîn Muḥammad b. Aḥmad b. 'Uthmân. Târîkh al-Islâm. 1. Dâr al-Gharb al-Islâmî,, 2003.

Al-Dhahabî, Shams al-Dîn Muhamammad b. Aḥmad. Mîzân al-I'tidâl. 1. Beirut: Dâr al-Ma'rifah, 1963.

Al-Ghâmidî, Aḥmad b. Sa'd Ḥamdân. al-Tashayu', Nash'atuhu wa Marâhịil Takwînuh. 1. Dâr al-Fu'âd, 2010.

Al-Gharîb, 'Abdullâh Muḥammad. Wa-Jâ'a Dawr Al-Majūs. Dar Al-Jîl, 1981. 
Al-Ghazâlî, Abū Ḥâmid Muḥammad b. Muḥammad. Fạ̣â'ḥ al-Bâținiyyah. Edited by 'AbdulRaḥmân Badawî. Kuwait: Dâr al-Kutub al-Thaqâfiyyah, n.d.

Al-Ghiṭ̂ি', Muhammad al-Ḥusayn âlKâshif. Aşl al-Shî‘ah wa Uşūliha. 1. Beirut: Dâr al-Aḍ̂â', 1990.

Al-Jarhị̂, Majdî b. 'Awaḍ. Manhaj al-Shî'ah al-Ithnâ 'ashariyyah fî Tafsîr alQur'ân. 1. the author, 2009.

Al-Jumaylî, 'Abdullâh. Badhl al-Majhūd fî Ithbât Mushâbahat al-Râfị̣h li alYahūd. 2nd. Vol. 1. Maktabat al-Ghurabâ' al-Athariyyah, n.d.

Al-Khuḍarî, Muhammad. Itmâm al-Wafâ' fì Sîrat al-Khulafấ'. Beirut: Al-Maktabah al-Thaqâfiyyah, 1982.

Al-Kulaynî, Muhammad b. Ya'qūb. Uşūl al-Kâfî. 1. Beirut: Manshūrât al-Fajr, 2007.

Al-Maqrîzî, Aḥmad b. 'Alî. Al-Mawâ 'iz wa al-I'tibâr bi Dhikr al-Khiṭt wa al'âthâr. Vol. 2. Beirut: Dâr al-Kutub al'ilmiyah, 1418 A.H.

Al-Mufîd, Muhammad b. Al-Nu'mân. al-Irshâd fî Ma'rifat Hujaj Allah 'alâ alî́bâd. 2. Mu'asasatâl-ulBayt, 2008.

Al-Mufĩd, Muhammad b. al-Nu'mân. Awâ'il al-Maqâlât. 1. Maṭba'at Muhr, 1413 $\mathrm{AH}$.

Al-Mundhirî, 'Abdul'aẓîm b. 'Abdulqawî b. 'Abdullâh. Mukhtasar Sahịh Muslim. 6. Edited by Muḥammad Nâsir al-Dîn Al-Albânî. 2 vols. Beirut: Al-Maktab al-Islâmî, 1987.

Al-Nawbakhtî, Ḥasn b. Mūsa. Firaq al-Sî'ah. 1. Beirut: Manshūrât al-Riḍâ, 2012.

Al-Qifầrî, Nâşir b. 'Abdullâh b. 'Alî. Uşūl Madhhab al-Shî'ah,. 2. the Islamic university of Muhammad Ibn Su'ūd, 1994.

Al-Qummî, 'Alî b. Ibrâhîm. Tafsîr Al-Qummî. Najaf: Maṭba'at al-Najaf, 1387AH.

Al-Qummî, Sa'd b. 'Abdullâh Abū Khalaf al-Ash'arî. al- Maqâlât wa al-Firaq. Edited by Muḥammad Jawâd Mashkūr. Tehran: Maṭba'at Ḥaydarî, 1321 $\mathrm{AH}$.

Al-Salūmî, Sulaymân 'Abdullâh. Uşūl al- Ismâ 'îliyah. 1. Dâr al-Faḍîlah, 2001. 
Al-Sawwâh, Țahâ 'Alî. Mawqif al-Azhar al-Sharîf min al-Shî' 'ah al-Ithnâ 'Ashriyah. 1. Cairo: Dâr al-Yusr, 2010.

Al-Shahrastânî, Muḥammad b. 'Abdul-Karîm. Al-Milal Wa al-Nihal. Muassasat alḤalabî, n.d.

Al-Suyūṭ̂, 'Abdul-Raḥmân b. Abū Bakr. al-Durr al-Manthūr fî alTafsîr bi alMa'thūr. Beirut: Dâr al-Fikr, n.d.

Al-Ṭabarî, Muhammad b. Jarîr. Tarîkh al-Rusul wa al-Mulūk. Vol. 4. Beirut: Dâr al-Turâth, 1387 AH.

Al-Ṭabațabâ'î, Sayyid Muḥammad Ḥusayn. Shî'ite Islam. Edited by Sayyid Ḥusayn Naşr. Translated by Sayyid Ḥusayn Naşr. University of New York Press, 1975.

Al-Ṭūsî, Abū Ja ‘far Muhammad b. al-Ḥasan. Talkhîş al-Shâfî. 1. Qum: Mu'assasat Intishârât al-Muhibbîn, 1928.

Al-Zabîdî, Muhammad b. Muhammad b. 'Abdul-Razzâq. Tâj al-'ârūs. Vol. 21. Cairo: Dâr al-ḥidâyah, n.d.

Amîn, Aḥmad. Fajr al-Islâm. 10. Beirut: Dâr al-Kitâb al-ârabî, n.d.

Boswoth, G.E. et al, ed. The Encyclopedia of Islam. leiden: Brill, 1997.

Dahlawî, Shâh 'Abdul'azîz Ghulâm. Mukhtaşar al-Tuhfah al-Ithna 'ashariyyah. Translated by Ghulâm Muhammad Al-Aslamî. Cairo: Al-Maṭba'ah alSalafiyyah, $1373 \mathrm{AH}$.

Guillaume, Alfred. Islam. 2. London: Penguin book, 1956.

Ibn Al-Athîr, 'Alî b. Abî al-Karam. al-Kâmil fí al-Târîkh. 1. Vol. 2. Beirut: Dâr alKitâb al-'Arabî, 1997.

Ibn al-Nadîm, Abū al-Farag Muḥammad b. Isḥâq. al-Fihrist. 2. Edited by Ibrâhîm Ramaḍân. Beirut: Dâr al-Ma'rifah, 1997.

Ibn Ḥajar, Aḥmad b. 'Alî b. Muḥammad al-'Asqalânî. Lîsân al-Mîzân. 2. Beirut: Mu'assasat al-A'lamî, 1971.

Ibn Ḥazm, Abu Muḥammad 'Ali b. Aḥmad b. Sa'îd. al-Fişal fí al-Milalal wa alAhwâ' wa al-Nihal. Cairo: Maktabat al-Khânjî, n.d. 
Ibn Kathîr, Abū al-Fidâ' Ismâ'îl b. 'Umar. Al-Bidâyah wa al-Nihâyah. Dâr Ihyâa' alTurâth al-'Arabî, 1988.

Ibn Manẓūr, Muhammad b. Makram. Lisân al-'Arab. Vol. 8. Beirut: Dâr Sâder, n.d.

Ibn Taymiyah, Aḥmad b. 'Abdu-lhalîm. Minhâj al-Sunnah al-Nabawiyyah fî Naqụ 'Aqấ'id al-Shî'ah wa al-Qadariyyah. Cairo: Dâr al-Hadîth, 2004.

kardan, Ridhah. Imamate and infallibility of Imams in the Qur'an. Translated by Sayyid Iraj Razzâqî. ABWA publishing and printing center, n.d.

Leaman, Oliver, ed. The encyclopedia of Qu'an. New York: Rotledge, 2006.

Stewart, Devin J. Encyclopedia of Islam and the Muslim World. Edited by Richard C. Martin. 2 vols. New York: Library of Congress, 2003.

Wellhausen, Julius. The religio-political Opposition Parties In Early Islam: The Khawârij\& Shî 'ites. Translated by 'Abd-Ulraḥmân Badawî. Cairo:: Maktabat al-Nahḍah al-Mişriyyah, 1958.

Zahîr, Iḥsân Ilâhî. al-Shî‘ah wa al-Tashayyu'. 10. Dâr al-Salâm, 1995. 